\title{
Postmodern Vision on COVID-19 Outbreak: A Risk Society Experience in Surakarta
}

\author{
Muhammad Alif Alauddin ${ }^{1 *}$ Faith Aqila Silmi ${ }^{2}$ Arief Noer Prayogi ${ }^{3}$ Yuyun Sunesti ${ }^{4}$ \\ ${ }^{1,2,3,4}$ Faculty of Social and Political Sciences, Universitas Sebelas Maret, Indonesia \\ *Corresponding author. Email: malifaaa@student.uns.ac.id
}

\begin{abstract}
As postmodern emphasizes the society into a deep interpretation of individual reality, the current coronavirus disease (COVID-19) pandemic should be postulated beyond review of medical sciences. Exploring that, this paper uses sociological approach to review social circumstances of risk community manifested by crowdfunding and social movement campaigning the healthy lifestyles amidst the outbreak. The emergence of online-based crowdfunding and social movement to sporadically help medical personnel get Personal Protective Equipment (PPE) in the spread of COVID-19 which affects more than 210 countries and territories around the world. Drawing on the risk society and reflexive modernization theory proposed by Ulrich Beck, this paper aims to examine crowdfunding cooperation as strengthening public awareness of the ongoing risk due to the COVID-19 outbreak. This paper uses qualitative data derived from doctors/medical personnel, donors, founders, and promotors involved in crowdfunding and social movement projects through depthinterview and literature collected from another scientific paper. This paper examines informant's perception of risk consciousness on that medical personnel by consolidating collective efforts in effectively supplying PPE. To this method, field research conducted in Surakarta reveals findings that doctors and medical personnel classified as most at risk to the COVID-19 transmission. They hold a profound influence on treating patients from the virus while they could be directly transmitted. There are 2 modernization stages in which Beck proposed as a theory and we used to explain the social circumstances under the COVID-19; reflex and reflection stage. Both draw the shifting period of dealing with the outbreak. This paper contributes to reaffirming socio-economic potentials in the extraordinary condition of pandemic by demonstrating that common feeling of risk and evinces the public sphere dramatically provokes to the crowdfunding motivation. The way people assume the medical personnel as a risk community finally constructs Ulrich Beck's theory on dealing with the postmodern phenomena.
\end{abstract}

Keywords: Risk Society, COVID-19, Postmodern, Crowdfunding, Social Movement

\section{INTRODUCTION}

At the beginning of 2020, the world was stricken by the coronavirus outbreak (SARS-CoV or SARSr-CoV) which infected the human respiratory system and was first reported in Wuhan, China. The virus transmission, according to medical research conducted by Antonio Cheuk-Pui Wong et al., infects people through bats and certain mammals [1]. As of August 26, 2020, in over 216 countries and regions worldwide, this outbreak has infected over 24,091,086 cases. [2] and regarded as the fastest-growing epidemic in the 21 st century. In less than one year, more than 824,173 confirmed deaths have been reported, which have never occurred apart from the 1918 Spanish flu pandemic that struck Europe during the World War. It has infected 500 million people with an estimated population of 17-50 million dead [3]. Coronavirus (COVID-19) and Spanish flu are medically similar and are both pneumonia disease that has spread by travel from human to human.

In the case of Indonesia, COVID-19 was first confirmed on March 2, 2020, which infected 2 residents in Depok City. That patient 01 reportedly has high mobility, that is, he had direct contact with a Japanese who became the $24^{\text {th }}$ confirmed case in Malaysia. Referring to the COVID-19 case report in early March, most of them are classified as imported cases. According to the Centre for Disaster Control and Prevention (CDC), the scientific intent of imported cases is patients who contract viruses originating from abroad or areas with infection [4]. It can therefore be concluded that people with worldwide mobility are the first group of patients infected to COVID19. 
In sociological reviews, an in-depth study can be conducted using a class approach in looking at the spread of COVID-19. As explained in Weber's thesis, society is divided into three classes based on household income and wealth i.e. the lower classes, the middle classes, and the upper classes. [5]. Firstly, individuals with high mobility were first exposed to the coronavirus, as explained on previous exposure. They are classified into the upper-class group because they have a record of international travel which incidentally is global-scale business cooperation. Secondly, three days after the first confirmed cases, the total number of recent cases spread to the domestic community [6], which is no longer caused by infected patients abroad, known as local transmission. Those who infected were middle-class people working in the officebased sector such as government employees, private employees domiciled in major cities in Indonesia. For this reason, Jakarta, as the province with the largest number of middle-class citizens in Indonesia, first implemented work-from-home policy and then affirmed with LargeScale Social Restrictions (PSBB). Thirdly, the virus is increasingly widespread to other cities and districts, which in fact are rural communities with the professions of farmers, breeders, laborers classified into a lower class.

Based on the aforementioned explanation, as this research uses risk society theory, that society is currently shifting towards a new era of modernity which is marked by the threat of uncertain risk [7]. There are three types of risk i.e. physical-ecological risk, social risk, and mental risk [8], and COVID-19 is categorized as the first one which comprises the biological risk produced by animals and transforms into epidemics. This risk eventually infects all human beings regardless of social class, educational level, age of group, occupation, etc. Thus, what groups of community are most vulnerable and at-risk to COVID-19? How does society anticipate the current modern threat in the form of COVID-19?

As Beck explained, the risk community is experienced in the short-term harm calculation [9] so that it merely defined that the doctor/health worker is the most likely representative of the risk community. Their occupation plays an important role in dealing with COVID-19 while potentially they are most susceptible due to direct contact with patients. Recognizing the following condition, there are many voluntary movements to help doctors and health workers keep protected from viruses by conducting health counseling and donating PPE through crowdfunding. Crowdfunding is arguably effective in drawing public attention to collectively assist the at-risk groups [10], in particular through social media and the Internet [11]. In the same way, social volunteers who are able to reach the lower-class [12] by campaigning for a healthy lifestyle amid outbreaks [13], because the wealth accumulates in the upper class while the risk precisely accumulates in the lower class. The research question in this paper is therefore to explore the motivation of crowdfunding and voluntary movements in Surakarta that highlight doctors and health workers.

\section{LITERATURE REVIEW}

An academic debate on risk society theory first initiated by Ulrich Beck has colored the treasures of sociology. Beck explained beforehand that risk society was formed due to the residue of industrial technology that developed in Europe in the early 20th century. Workers at the industry sectors face a variety of deadly risks of both work safety and welfare [14]. These circumstances lead workers caught up in the endless uncertainty that is accumulated communally. Beck, in his analysis observed the behavior and condition of the workers and grouped it what is currently referred to as the risk society theory.

Ekberg's in-depth study of risk society in his study explores now that risk coverage has holistically spread to the sociopolitical values of equality, liberty, justice, democracy, and rights. [15]. The study explained that the risk to Beck should be updated with technological advances and enhancing the future research that is further classified into several parameters. Not only to environmental damage [16] or technological hazard, the cause of risk is now shifting to the paradigm with the omnipresence of source (see figure 1).

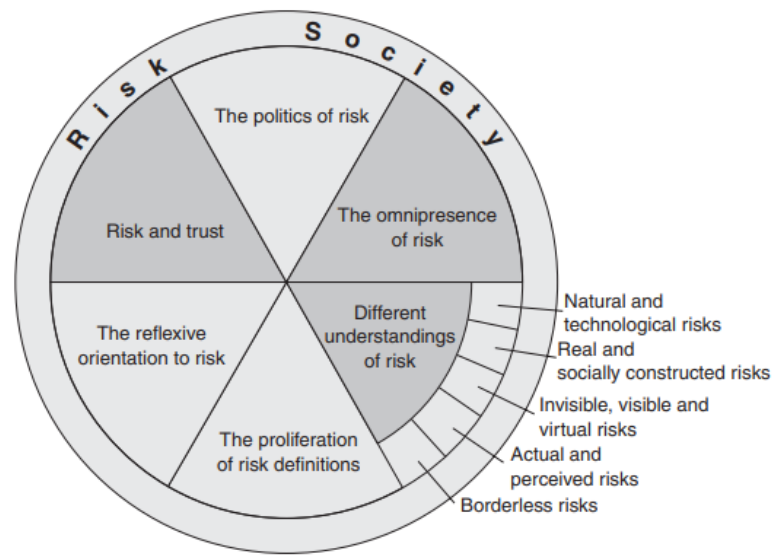

Figure 1. Contemporary Parameters of the Risk Society (Ekberg, 2007)

In emphasizing risk as a concept of sociological study, it is necessary to conceive the interlinked social processes itself. As explained on Mythen's study [17], changes in social distribution patterns in postmodern society are supported by changes between capital and labor in employment that lead to risks. The explanation reaffirms indeed a form of risk demonstrates how industrial society is under uncertainty. Such conditions will implicate to epochal breaks where awareness of the risks increases, it is what so-called reflexive modernity.

\section{METHODS}

This study used a case study as a methodology in exploring novelty research we conducted in Surakarta. The case study was chosen as a research tool as it could describe the research question deeply and in a detailed 
following the qualitative procedures [14]. In collecting data, the authors interviewed 6 informants who had carried out the capability selection process so that the information provided is in accordance with the research question. This is a structured-purposive interview derived from the doctor/medical personnel, donor, founder, and promotor involved in the crowdfunding project as attached in Table 1. All the data obtained are corresponding to the transcript that each lasting for 30-40 minutes. The research questions which the authors further describe in the interview guidelines consist of 15 general questions and 8 specific questions which in each cluster contain different type. This is to deepen the informant's role in this movement they involved [15].

Table 1: Research Participants

\begin{tabular}{|c|c|c|}
\hline Code & Occupation & Association \\
\hline M1 & $\begin{array}{l}\text { Young } \\
\text { doctor }\end{array}$ & Dr. Moewardi Hospital \\
\hline M2 & $\begin{array}{l}\text { Young } \\
\text { doctor }\end{array}$ & UNS Hospital \\
\hline M3 & Core team & Solo Melawan Corona \\
\hline M4 & Founder & $\begin{array}{l}\text { President of Indonesian Red } \\
\text { Crescent (BSMI) of Surakarta }\end{array}$ \\
\hline M5 & Donor & $\begin{array}{l}\text { Coordinator of Young Islamic } \\
\text { Medical Association and } \\
\text { Network of Indonesia } \\
\text { (Prokami Muda) }\end{array}$ \\
\hline M6 & Promotor & $\begin{array}{l}\text { Faculty of Medicine, Sebelas } \\
\text { Maret University }\end{array}$ \\
\hline
\end{tabular}

The informant we interviewed were young doctors at Dr. Moewardi Hospital and UNS Hospital which in this case is a referral hospital for COVID-19 in Surakarta and Central Java province. In addition, one of the informants is a coordinator of Young Islamic Medical Association and Network of Indonesia (Prokami Muda) in Surakarta and President of Indonesian Red Crescent (BSMI) of Surakarta in which both institutions actively initiated a voluntary movement to donate PPE. Furthermore, a mass-collective movement involved in campaigning for a healthy lifestyle also included, namely Solo Melawan Corona. All of the above-mentioned have met the criteria of a case design study consisting of various experiences gathered in a common cause which in this circumstance is a crisis community due to COVID-19. The Interview was conducted using two methods 1) face-to-face research (FTF), where authors met the informants directly and 2) telephony-mediated Research (TMR), where authors used mobile phone intermediaries. We finally did a data reduction process consisting of interviews, observations, and documentation. This is to be used in the data selection process, simplification, abstracting as well as concluding the data obtained [16].

\section{RESULTS AND DISCUSSIONS}

\subsection{REFLEXSIVE MODERNIZATION AS MODERN CONSCIOUSNESS}

In an industrial society with a wide range of risks, it has become accustomed to preparing solutions both in the long and in the short term. This pattern is a response to the uncertainty that is threatening social order due to the development of science. [17]. That condition is a causal effect due to awareness of the risks involved. According to Beck, this awareness is reflected in the behavior of the most particularly postmodern society in Europe, which is experiencing the development of the production and manufacture of so-called reflexive modernization; the acceptance of the reality of modernity [18]. This is impactful to post-modern societies that are adaptable to social change complemented by industrial development.

As Beck emphasized the risk society theory based on technological developments that leads to a man-made ecological disaster [19], the case of COVID-19 can be classified as an unintended threat due to its massive transmission. Reviewed using this approach, there are two stages of reflexive modernization i.e. the reflex stage and the reflection stage. The core notion of the reflex stage is the beginning of something that is considered risky created by modernization but they are not recognized. At this point, the catastrophe of the industrialization process slowly started to occur, but the community did not realize properly. Furthermore, the reflection stage is defined as a change in the perspective of ordinary people towards a risk society. More specifically, communities begin to coexist and live with the risk-taking. At this stage, as Beck noted, the individuals must certain the uncertainty caused by constant insecurity [20].

According to research we conducted, there are four dimensions of reflexive modernization described in Table 2 , i.e. mass psychology, daily routine, affected sectors, and core institution in charge of. The reason is that when COVID-19 began to infiltrate to Indonesia, people of Surakarta felt a common sense of fear. They argued that COVID-19 is very dangerous as it causes death. The fear is mostly felt by the entire individuals, particularly in early March and April. This condition causes individuals to be reluctant to leave the house instead of being afraid of being infected. They consider staying at home until the condition returns to normal. Using Beck's approach, fear is a reflex stage where individuals begin to accept risks from the development of science. That response is considerably spontaneity which is not based on preliminary scientific studies.

In addition, the Surakarta City Government on March 14, 2020, issued a Decree of the Mayor of Surakarta Number 443.76 / 28 of 2020 on the 
Determination of the Status of Extraordinary Occurrence of Corona Virus Disease (COVID-19) in Surakarta City. This decree regulates social restrictions such as closing schools starting from kindergarten to high school both public and private for 14 days, closing sports facilities including Manahan and Srwiwedari sports arena, closing all tourist destinations, canceling work visits to and from Surakarta City, and the most highlighted policy is to burned hundreds of bats confiscated from traders at Depok Market. The policy of social restrictions caused the mobility of the population to become limited. As in the education sector, young doctors cannot freely gain field practice experience in the professional programme at Dr. Moewardi Hospital and UNS Hospital, since both hospitals are used as primary referrals for COVID-19 patients in Surakarta and Central Java Province.

"The indirect impact of COVID-19 on us is deeply disturbing to academic achievement. Because as a young doctor, we should have a strong experience in field practice. What's the difference with pre-clinical students, then?" (Informant M1: Ahmad Yasin, July 29, 2020)

Moreover, at the reflex stage, the public refused that only health is the sector most affected by COVID-19. Doctors and medical personnel are the people most vulnerable to this outbreak indeed. The medical personnel's safety is particularly at risk as the number of patients exposed is increasing. If hospitals across Indonesia have high-quality services and medical devices, there will be no disparity between the provinces with the highest and lowest cases.

"Just look right now. It should be with the concept of decentralization that Indonesia applies that hospitals in each region can meet the same quality standards. So, when there are patients, they won't spread to other provinces." (Informant 5: M Adil, July 25, 2020)

Table 2: Reflexive Modernization's Dimension due to COVID-19

\begin{tabular}{lll}
\hline & Reflex Stage & Reflection Stage \\
\hline $\begin{array}{l}\text { Mass } \\
\text { psychology }\end{array}$ & Fear & $\begin{array}{l}\text { Risk } \\
\text { Consciousness }\end{array}$ \\
\hline Daily routine & Strict mobility & $\begin{array}{l}\text { Applying health } \\
\text { protocols }\end{array}$ \\
\hline Affected sector & Health & Multisector \\
\hline $\begin{array}{l}\text { Core institution } \\
\text { in charge of }\end{array}$ & Hospital & $\begin{array}{l}\text { Central and local } \\
\text { government }\end{array}$ \\
\hline
\end{tabular}

However, after moving towards the stage of reflection, people's stigmatization changes in precepting the risk. They were currently more adaptable and aware of the risk. The purpose of risk awareness is that each individual realizes that they are under a threat from COVID-19. In this matter, we found a lot of social movements which is mostly initiated by students and youth.

"I participated in a campus-induced community service program (KKN) concentrating in dealing with COVID-19. I did the programme in RT1/18 Jebres District."

(Informant M5: M Adil, July 25, 2020)

"Solo Lawan Corona (Solo fight against Corona) movement as a medium to educate the public by means of media campaigns and direct socialization in public places such as markets, terminals, and stations".

(Informant M3: Muhammad Shidiq Fathoni, 20 August, 2020)

Figure 2. Socialization conducted in market

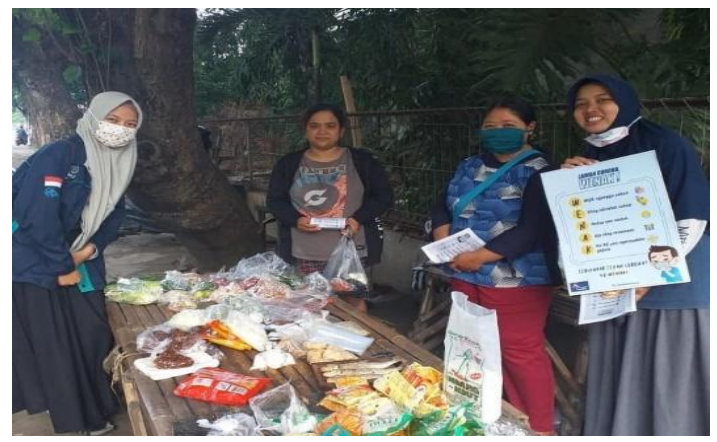

At this stage too, the community begins to carry out its usual activities by applying health protocols. Reaffirming by Circular Letter of The Mayor of Surakarta No. 067/1078 on Technical Guidelines for The Implementation of Corona Virus Disease Treatment in Surakarta which regulates economic activity, tourism, and entertainment during a pandemic. Some of the regulated points include prohibiting every child and parent from entering markets, shopping centers, tourist attractions. obliging to carry out health protocols by providing a place to wash hands with clean running water and soap, providing a body temperature check (thermogun), providing hand sanitizer, wearing a mask, maintaining a safe distance of at least 1 meter (physical distancing), refusing visitors/buyers/customers who do not wear masks. Changes in the reflection phase continue with people's perceptions of COVID-19 sectors. They have previously assumed that it is only the healthcare sector but now the effect is felt across human life sectors were extremely hit. The economy is one of the worst-affected. Home expenditures are increasing to satisfy diet preventing the COVID-19 transmission. Moreover, the education sector is one of the most affected in addition to the economy since schools of all levels are closed in Indonesia by 2021 as 
refers to Joint Ministerial Decree on Learning Guidelines during COVID-19 Pandemic. Including universities that have finally implemented an online distance learning policy. This is considered to be ineffective because there is no direct contact between the lecturer and the students that are emotionally important in the learning process.

"Now, household purchases are soaring to meet the needs of vitamins, milk, masks and personal protective equipment"

(Informant M1: Ahmad Yasin, July 29, 2020)

"In-class learning for medical student is necessary. Then, online learning is not effective as there is no direct contact with the lecturer."

(Informant M5: M Adil, July 25, 2020)

Continuing which institutions should be most responsible for dealing with outbreaks, in previous phases, society relied on hospitals and health institutions. But as it shifts to the reflection stage, individuals are assuming that addressing that local and central governments are in charge of overcoming the COVID-19. In a risk society, there is no dependence at all on certain institutions [7][8][9] due to a top-down industrial-style relationship. In this case, because of their power over citizens, the government should seriously prepare strict rules on community mobility regulation. People assumed that at the beginning of the pandemic in Indonesia the government did not well-responsive to disaster mitigation.

"The government seems to be underestimating COVID-19. If strict regulations had been implemented, this would not have happened."

(Informant M1: Ahmad Yasin, July 29, 2020)

\subsection{CROWDFUNDING AND SOCIAL MOVEMENT PARTICIPATION IN DISTRIBUTING PERSONAL PROTECTIVE EQUIPTMENT (PPE)}

As explained in the previous discussion, various social movements have emerged to raise awareness of the threat of COVID-19 transmission. One of the most perceived is a crowdfunding movement to distribute personal protective equipment (PPE) to frontline health care workers. Hence, the need for (PPE) is very important considering the risk of transmission in the hospital is more hazardous so that threatens medical workers [21]. Reflecting on Beck's theory, the condition strongly illustrates how risk society lived in uncertainty, and so need the help of others [8].

Medical personnel consisting of doctors and nurses must wear PPE in accordance with the procedures applicable to the health protocol. For those working in general or specialist polyclinics who do not take care of COVID-19 patients using level 2 PPE is a must which consists of disposable apron; long-sleeved fluid repellent or disposable gown, disposable gloves, eye protection both full-face visor or goggles and FFP3 mask. However, the availability of PPE for medical personnel at Both Dr. Moewardi Hospital and UNS Hospital was so limited in the early days of the pandemic then likely threatened their safety.

"We (medical workers) used to run out (PPE). But since April there have been many (PPE) donations from NGOs and universities"

(Informant M1: Ahmad Yasin, July 29, 2020)

"Before entering the hospital, we had to put on level 2 PPE and being sterilized"

(Informant M2: Bukhori Ahmad Muslim, July 24, 2020)

That limited distribution has prompted initiatives from civil society to encourage donations for frontline medical workers. All informants we interviewed agreed that medical personnel is the most vulnerable professions infected with COVID-19 because they make physical contact directly with patients. This has prompted various NGOs and civil society to raise funds to ensure the safety of medical personnel.



Figure 3. Handover of PPE to Sibela Public Health Center

With the existence of COVID-19 in the City of Surakarta, which has an impact on various sectors, the risk society theory applies to the entire community and set medical workers as the most vulnerable group. The distribution of the PPE is focused on public health centers (Puskesmas) which are scattered in each sub-district because it is the first referral to the middle to lower-class people who are unable to access the main hospital in Surakarta City. Protection for medical personnel at the sub-district level is induced due to its limited number of medical personnel in dealing with COVID-19 patients. 
"The PPE is needed the most in hospitals and clinics. And at that time, even in Solo City, it was still quite difficult to have."

(Informant M4: Kiemas Tegar Indrawan, August, 23, 2020)

In addition, socialization to maintain health is also carried out by students who are either involved in collective movements such as Solo Lawan Corona or individuals. Most are initiated by medical students who expertly do have advanced experience and science specializations campaigning the importance of maintaining health and building awareness of COVID-19 transmission. The reason the doing so is that everyone can protect themselves, their family, and surroundings in the smallest possible scale. This behavior is a cooperation works reflecting the culture of the risk community. [19].

"I personally hold the status as a medical student, yet I realize the expertise I am currently majoring could enhance public health a lot. Then, I just donate”.

(Informant M6: Kayyis Hawari, August 22, 2020)

\section{CONCLUSION}

The COVID-19 outbreak has transformed the social order into a more complex one. This paper examines the social changes taking place in the city of Surakarta using the theory of risk society and reflexive modernization proposed by Ulrich Beck. The findings explain that two different conditions are facing an outbreak, i.e. the reflex stage and reflection stage. In the reflex stage, individuals tend to be passive and helpless, as explained in the abovementioned dimensions. But when it shifts to the stage of reflection, they begin to open up and get used to living along at risk. The next finding is that there is a collective awareness that characterizes the risk community, it is the emergence of a social movement to campaign for a healthy lifestyle and the initiation of PPE for medical personnel. This activity aims to protect all individuals and medical personnel in Surakarta because they are at the forefront of dealing with COVID-19 patients.

\section{REFERENCES}

[1] Wong, A., Li, X., Lau, S., \& Woo, P. (2019). Global Epidemiology of Bat Coronaviruses. Viruses, 11(2), 174. MDPI AG. Retrieved from http://dx.doi.org/10.3390/v11020174

[2] Coronavirus disease (COVID-19) pandemic. (7 August 2020) Retrieved on 26 August 2020 from https://www.who.int/emergencies/diseases/novelcoronavirus-2019

[3] Tsoucalas, G., Kousoulis, A., \& Sgantzos, M. (2016). The 1918 Spanish Flu Pandemic, the Origins of the H1N1-virus Strain, a Glance in History. European Journal of Clinical and Biomedical Sciences, 2(4), 23 28.

[4] Putsanra, Dipna Videlia. (2020). Arti Imported Case, Salah Satu Kasus Corona COVID-19 di Indonesia. Retrieved on 8 August from https://tirto.id/eD4F

[5] Gane, N. (2005). Max Weber as Social Theorist: 'Class, Status, Party'. European journal of social theory, 8(2), 211-226.

[6] Prawira, Aditya Eka. (2020). 27 Orang Positif Corona di Indonesia, Ada 1 Kasus Local Transmission. Retrieved on 8 August 2020, from https://www.liputan6.com/health/read/4198591/27orang-positif-corona-di-indonesia-ada-1-kasus-local$\underline{\text { transmission }}$

[7] Demartoto, Argyo. (2013). TEORI MASYARAKAT RISIKO DARI ULRICH BECK. Retrieved on 8 August from https://argyo.staff.uns.ac.id/2013/03/14/teorimasyarakat-risiko-dari-ulrich-beck/

[8] Beck, U., Lash, S., \& Wynne, B. (1992). Risk society: Towards a new modernity (Vol. 17). sage.

[9] Lidskog, R. (1993). Book Reviews: Ulrich Beck: The Risk Society. Towards a New Modernity. London: Sage, 1992. Acta Sociologica, 36(4), 400-403.

[10] Bagheri, A., Chitsazan, H., \& Ebrahimi, A. (2019). Crowdfunding motivations: A focus on donors' perspectives. Technological Forecasting and Social Change, 146, 218-232.

[11] Borst, I., Moser, C., \& Ferguson, J. (2018). From friendfunding to crowdfunding: Relevance of relationships, social media, and platform activities to crowdfunding performance. new media \& society, 20(4), 1396-1414.

[12] Salido-Andres, N., Rey-Garcia, M., AlvarezGonzalez, L. I., \& Vazquez-Casielles, R. (2020). Mapping the field of donation-based crowdfunding for charitable causes: systematic review and conceptual framework. VOLUNTAS: International Journal of Voluntary and Nonprofit Organizations, 1-15. 
[13] Alegre, I., \& Moleskis, M. (2019). Beyond Financial Motivations in Crowdfunding: A Systematic Literature Review of Donations and Rewards. VOLUNTAS: International Journal of Voluntary and Nonprofit Organizations, 1-12.

[14] Beck, U. (2009). Critical theory of world risk society: a cosmopolitan vision. Constellations, 16(1), 322.

[15] Ekberg, M. (2007). The parameters of the risk society: A review and exploration. Current sociology, 55(3), 343-366.

[16] Alauddin, M. A., Pribandono, A. A., Saputri, F. D., Pramukti, N. H. N., Sari, K. P., Menawati, R. S., \& Putri, A. K. PERILAKU MASYARAKAT KOTA: TELAAH KRISIS EKOLOGI DI KECAMATAN SERENGAN KOTA SURAKARTA. Jurnal Analisa Sosiologi, 9.

[17] Mythen, G. (2005). Employment, individualization and insecurity: rethinking the risk society perspective. The Sociological Review, 53(1), 129-149.

[18] Kusmarni, Y. (2012). Studi Kasus. UGM Jurnal Edu UGM Press.

[19] Miles, Mathew B., dan A. Michael Huberman. (1994). An Expanded Sourcebook: Qualitative Data Analysis. London: Sage Publications.

[20] Rachmawati, I. N. (2007). Pengumpulan data dalam penelitian kualitatif: wawancara. Jurnal Keperawatan Indonesia, 11(1), 35-40.

[21] Wimmer, J., \& Quandt, T. (2006). Living in the risk society: an interview with Ulrich Beck. Journalism Studies, 7(2), 336-347.

[22] Gleeson, B. (2000). Reflexive modernization: The re-enlightenment of planning?. International Planning Studies, 5(1), 117-135.

[23] Beck, U., Bonss, W., \& Lau, C. (2003). The theory of reflexive modernization: Problematic, hypotheses and research programme. Theory, culture \& society, 20(2), 1-33.

[24] Lash, S. (1993). Reflexive modernization: The aesthetic dimension. Theory, Culture \& Society, 10(1), $1-23$.

[25] Ranney, M. L., Griffeth, V., \& Jha, A. K. (2020). Critical supply shortages - the need for ventilators and personal protective equipment during the Covid-19 pandemic. New England Journal of Medicine, 382(18), e41. 